\title{
Investigation of the effects of season, milking region, sterilisation process and storage conditions on milk and UHT milk physico-chemical characteristics: a multidimensional statistical approach
}

\author{
Isabelle GAUCHER ${ }^{1}$, Tahar Boubellouta ${ }^{2}$, Eric BeAUCHER ${ }^{1}$, Michel Piot $^{1}$, \\ Frédéric GAUCHERON ${ }^{1}$, Eric DUFOUR ${ }^{2 *}$ \\ ${ }^{1}$ INRA, Agrocampus Rennes, UMR1253, Science et Technologie du Lait et de l'Euf, \\ 65 rue de Saint-Brieuc, 35042 Rennes Cedex, France \\ ${ }^{2}$ UR Typicité des Produits Alimentaires, ENITA de Clermont-Ferrand, Site de Marmilhat, \\ BP 35, 63370 Lempdes, France
}

Received 25 May 2007 - Accepted 3 November 2007

\begin{abstract}
Milk samples were collected in five dairy plants located in different regions of France (North, North-West, South-West and centre of France), during spring and autumn, at receipt (bulkraw milk), and following pasteurisation and UHT sterilisation. Corresponding UHT milks were then stored at three temperatures $\left(4,20\right.$ and $\left.40{ }^{\circ} \mathrm{C}\right)$ and analysed after different times $(21,42,62,90,110$ and $180 \mathrm{~d}$ ). The physico-chemical characteristics of these different milks, including composition, micellar properties and stability as assessed by heat, ethanol and phosphate tests, were determined. The database was processed by principal component analysis and common components and specific weights analysis. The effects of season, milking zone, process and storage conditions were highlighted, and the involved physico-chemical characteristics were determined. For the region effect, numerous parameters related to the global composition and the casein micelles intervened. Some differences in milk stability as evaluated by the ethanol and phosphate tests were also observed. Considering the season, spring milks had higher values of $\mathrm{pH}$, lactose, soluble phosphate and micellar hydration than milks collected in autumn. These spring milks also had lower values of fat and heat stability than autumn milks. The UHT process effect was observed through decreases in non-casein nitrogen content and in micellar hydration and by an increase in casein micelle size for UHT milks. The stability values derived from phosphate and ethanol tests were increased following the UHT process. Concerning storage conditions, the temperature of $40{ }^{\circ} \mathrm{C}$ led to a decrease in $\mathrm{pH}$ and increases in non-casein and non-protein nitrogen contents of milks. At $40{ }^{\circ} \mathrm{C}$, low values of stability for the heat test and high values for the phosphate test were observed.
\end{abstract}

\section{UHT milk / physico-chemical composition / stability / casein micelle / chemometry}

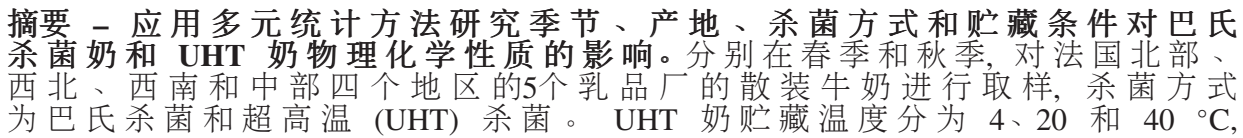

* Corresponding author (通讯作者): dufour@enitac.fr 
㲸藏时间为 $21 、 42 、 62 、 90 、 110$ 和 $180 \mathrm{~d}$ 。测定了不同咜藏条件下 UHT 奶的组成, 研究了 热处理对酪蛋白胶束特性和稳定性的影响, 以及牛奶的乙醇和磷酸盐试验。采用主成分分 析、普通组成分析和权重分析法对试验数据进行统计分析。研究发现牛奶的生产季节、产 地、条菌方式和只藏条件对牛奶理化性质有显著的影响。根据对所有成分的分析、与酪蛋 白胶束相关的试验, 以及乙醇和磷酸盐试验等大量实验数据分析, 证明了不同地区牛奶的稳 定性之间有一定的差异。在牛奶生产季节上的差异则是, 春季牛奶的 $\mathrm{pH}$ 、乳糖含量、可溶 性磷酸盐含量和酪蛋白胶束的水合能力均高于秋季牛奶, 春季牛奶的脂肪含量和热稳定性 均低于秋季牛奶。对 UHT 奶, 通过降低非酪蛋白氮含量和酪蛋白胶束水合作用以及增大酪 蛋白胶束尺寸的方法研究了 UHT 过程对其影响, 乙醇和磷酸盐试验证明经上述方法处理的 UHT 奶稳定性增加。在 $40^{\circ} \mathrm{C}$ 下咜藏的牛奶 $\mathrm{pH}$ 降低, 而非酪蛋白氮和非蛋白氮含量增加; 并 且在 $40{ }^{\circ} \mathrm{C}$ 下败藏的牛奶热稳定性值较低, 但其磷酸盐试验的测定值较高。

\section{UHT奶 / 物理化学性质 / 稳定性 / 酪蛋白胶束 / 化学计量}

Résumé - Étude des effets saison, région laitière, traitement de stérilisation et conditions de stockage sur les caractéristiques physico-chimiques du lait et du lait UHT : une approche statistique multidimensionnelle. Des échantillons de lait ont été collectés dans cinq laiteries situées dans différentes régions de France (Nord, Nord-Ouest, Sud-Ouest et centre de la France), au printemps et en automne, à la réception (laits crus de mélange), après pasteurisation et après stérilisation UHT. Les laits UHT correspondants ont ensuite été placés à trois températures $(4,20$ et $40{ }^{\circ} \mathrm{C}$ ) et analysés après différents temps de stockage $(21,42,62,90,110$ et $180 \mathrm{j})$. Les caractéristiques physico-chimiques de ces différents laits, comprenant la composition, les propriétés micellaires et la stabilité évaluée à l'aide des tests à la chaleur, à l'alcool et au phosphate, ont été déterminées. Le jeu de données a été étudié par analyse en composantes principales et analyse en composantes communes et poids spécifiques. Les effets de la saison, de la région de collecte, du traitement technologique et des conditions de stockage ont été mis en évidence et les caractéristiques physico-chimiques impliquées ont été déterminées. Pour l'effet région, de nombreux paramètres liés à la composition globale et aux micelles de caséines intervenaient. Des différences de stabilité du lait, évaluée par les tests à l'alcool et au phosphate, ont aussi été observées. Considérant la saison, les laits de printemps avaient des valeurs de $\mathrm{pH}$, de lactose, de phosphate soluble et d'hydratation micellaire plus grandes que les laits collectés en automne. Ces laits de printemps avaient aussi des valeurs plus faibles de matière grasse et de stabilité thermique que les laits d'automne. L'effet traitement UHT a été observé au travers d'une diminution de la teneur en azote non caséinique et de l'hydratation micellaire et par une augmentation de la taille des micelles. Les valeurs de stabilité des laits obtenues par les tests au phosphate et à l'alcool augmentaient après le traitement UHT. Concernant les conditions de stockage, la température de $40{ }^{\circ} \mathrm{C}$ induisait une diminution du $\mathrm{pH}$ et des augmentations des teneurs en azote non caséinique et non protéique des laits. $\grave{A} 40{ }^{\circ} \mathrm{C}$, des valeurs faibles de stabilité dans le test à la chaleur et des valeurs élevées de stabilité dans le test au phosphate ont été observées.

\section{lait UHT / composition physico-chimique / stabilité / micelle de caséine / chimiométrie}

\section{INTRODUCTION}

Milk is a complex product, constituting three phases: a fat emulsion, a casein micelle dispersion and an aqueous phase containing mainly lactose, whey proteins and minerals [1]. Its composition can be influenced by numerous factors such as cow genetic (breed) [10], physiologic (animal medical state, lactation number and stage) $[28,29,40]$ and zootechnic factors (feed, milking conditions, exercise) $[5,11]$.
Some of these factors may be correlated to other parameters such as region of production [22], season $[3,12,18]$ or social practice in herd management [4], for example.

In addition to its natural and individual variability, milk is a sensitive product whose properties may be altered by various factors such as microbial contamination. To destroy micro-organisms and inactivate enzymes in order to increase milk shelf-life, technological treatments, and particularly heat treatments such as UHT 
sterilisation, can be applied to milk. This last technique offers a "commercially sterile" product which can be stored at ambient temperature for several months. However, UHT processing and storage are not harmless and induce different changes in milk depending on the time-temperature parameters [8]. Sometimes these changes lead to UHT milk destabilisation during storage as a gel or a sediment $[7,25]$. Parameters which affect milk stability have been reported such as composition parameters, process and storage conditions [27]. Nevertheless, all these studies about milk generally considered only one or few physicochemical characteristics and focused on one part of the life of the product (raw milk, manufacture or storage).

In the present study, the objective was to determine, on a large data set, by a multidimensional statistical approach, the possible effects of season, milking region, sterilisation process and storage conditions on milk and UHT milk physicochemical characteristics. For that, we analysed changes which occurred in five bulkraw milks during UHT processing and storage for six months at three temperatures. These five bulk-raw milks were collected in dairy plants located in different regions of France. Sampling was performed in spring and autumn. The studied physico-chemical characteristics refered to global milk characteristics $(\mathrm{pH}$, total solids, fat, lactose, proteins, nitrogen fractions such as NCN and NPN contents, concentrations in soluble calcium and phosphate), casein micelle properties (size, charge, hydration) and stability evaluated by three tests (heat, ethanol and phosphate tests).

\section{MATERIALS AND METHODS}

\subsection{Milk collection}

The study focused on five bulk-raw milks sampled in five dairy plants, called V,
$\mathrm{W}, \mathrm{X}, \mathrm{Y}$ and $\mathrm{Z}$. These dairy plants were located in different regions of France: North, North-West, South-West and centre, and the volumes of milk treated by each one comprised between $200000 \mathrm{~L}$ and $900000 \mathrm{~L}$ of milk per day. Milks mainly came from Prim'Holstein cows, but also from other breeds such as Pie Noire, Montbéliarde and Salers. According to the season, cows were fed with hay, corn grain or silage, oat, concentrates or were put on pasture. Milking was usually done twice a day. Raw milks were generally collected every $48 \mathrm{~h}$, or at maximum, every $72 \mathrm{~h}$. In the dairy plants, raw milks were stored in tanks of capacity between 100000 and $250000 \mathrm{~L}$.

Concerning the manufacture of UHT milk in the dairy plants, it globally consisted of: (1) cooling of bulk-raw milk at $4{ }^{\circ} \mathrm{C}$; (2) skimming between 30 and $50{ }^{\circ} \mathrm{C}$; (3) pasteurisation (between 80 and $90{ }^{\circ} \mathrm{C}$ for 10 to $30 \mathrm{~s}$, depending on the plant); (4) fat standardisation at about $15 \mathrm{~g} \cdot \mathrm{kg}^{-1}$; (5) cooling and storage of milk before homogenisation or direct homogenisation (between 25 and 200 bars at temperatures between 72 and $92{ }^{\circ} \mathrm{C}$ ); (6) UHT sterilisation $\left(140{ }^{\circ} \mathrm{C}\right.$ for 3 to $6 \mathrm{~s}$, depending on the plant), and (7) aseptic filling. In this study, milks were collected before any treatment (bulk-raw milks), after pasteurisation and then after UHT sterilisation and aseptic filling. Raw, pasteurised and freshly processed UHT milks were analysed and abbreviated as follows: "r", "p" and "u", respectively. The UHT milks corresponding to the bulk-raw milks initially considered and treated were semiskimmed UHT milks. These UHT milks were stored at three temperatures (4, 20 and $40{ }^{\circ} \mathrm{C}$ ) and analysed after different storage periods $(21,42,62,90,110$ and $180 \mathrm{~d}$ ). This milk sampling was realised for two seasons, i.e. spring and autumn (cited as "1" and "2", respectively).

Bulk-raw and pasteurised milk samples were kept at $4{ }^{\circ} \mathrm{C}$ for a maximum 
of 2 days before analyses and thimerosal $0.03 \%$ (w/w) (Sigma, Saint-Louis, USA) was added to prevent further microbial development. The temperature was raised to $20{ }^{\circ} \mathrm{C}$ just $1 \mathrm{~h}$ before analyses. Concerning UHT milks stored at 4 and $40{ }^{\circ} \mathrm{C}$, samples were put at room temperature for equilibrium approximately $15 \mathrm{~h}$ before analysis. All UHT milks were checked for total mesophilic aerobic flora and psychrotrophic flora contaminations. Thimerosal $0.03 \%(\mathrm{w} / \mathrm{w})$ was also added to all UHT milks after microbiological control in order to prevent further microbial contamination.

\subsection{Physico-chemical analyses}

\subsubsection{Milk stability tests}

Heat stability was valued as the Heat Clotting Time (HCT). It was determined on $5 \mathrm{~mL}$ of milk in sealed Pyrex tubes fitted into a thermostatically controlled oil bath at $140{ }^{\circ} \mathrm{C} \pm 1{ }^{\circ} \mathrm{C}$. The time (in min) necessary to obtain a visible destabilisation was considered as the result of the test [9].

The ethanol test (Alcohol) consisted of the addition of $1 \mathrm{~mL}$ of an ethanol solution to $1 \mathrm{~mL}$ of milk. Ethanol concentrations ranged from 50 to $95 \%$ (v/v) with increments of $5 \%(\mathrm{v} / \mathrm{v})$. The mixture was stirred vigorously and the reading was done in 5 min. The lowest concentration (in \%) giving a flocculation was defined as the result of the test [37]. Milks which were not destabilised by $95 \%$ of ethanol were considered as being $100 \%$.

For the phosphate test (Ramsdell), milk samples $(10 \mathrm{~mL})$ were placed in sealed Pyrex tubes and volumes of $\mathrm{KH}_{2} \mathrm{PO}_{4} \quad 0.5 \mathrm{~mol} \cdot \mathrm{L}^{-1}$ (Panreac Quimica SA, Barcelona, Spain) were gradually added to each tube. After mixing, tubes were heated at $100{ }^{\circ} \mathrm{C} \pm 1{ }^{\circ} \mathrm{C}$ for $10 \mathrm{~min}$. After the heat treatment, the smallest volume of phosphate solution (in $\mathrm{mL}$ ) resulting in milk destabilisation was considered as the result of the test [31].

\subsubsection{Milk composition}

Milk pH was measured using a HI 9024 pH-meter (Hanna Instruments, Vila do Conde, Portugal). Gross composition of milks such as concentrations of fat, lactose, proteins and total solids $\left(\mathrm{g} \cdot \mathrm{kg}^{-1}\right)$ was obtained by an infrared spectrometer Lactoscope (Delta Instruments, Drachten, Holland). Non-casein nitrogen (NCN) content was determined on the filtrate of milk acidified to $\mathrm{pH} 4.6$ with a mixture of $10 \%(\mathrm{v} / \mathrm{v})$ acetic acid and $1 \mathrm{~mol} \cdot \mathrm{L}^{-1} \mathrm{ac}-$ etate buffer. Non-protein nitrogen (NPN) content was determined on the filtrate of 1:4 mixtures of milk and $15 \%(\mathrm{w} / \mathrm{v})$ trichloroacetic acid solution (TCA). The filters used were Whatman ${ }^{\circledR} \mathrm{N}^{\circ} 42$ and 40 for NCN and NPN, respectively. Nitrogen content was determined by the Kjeldahl method (IDF standard 20B, 1993) and converted into equivalent protein contents $\left(\mathrm{g} \cdot \mathrm{kg}^{-1}\right)$ using 6.25 and 6.19 as converting factors for NCN and NPN contents, respectively. Concentration of soluble calcium was determined on the milk ultrafiltrate with an atomic absorption spectrometer (Varian 220FS spectrometer, Les Ulis, France) [6]. Concentration of soluble phosphate was determined on the milk ultrafiltrate using ion chromatography (Dionex DX 500, Dionex, Voisin-le-Bretonneux, France) [16]. Soluble concentrations were corrected by the factor 0.96 as determined by Pierre and Brulé [30]. Mineral concentrations were expressed in $\mathrm{mmol} \cdot \mathrm{L}^{-1}$.

\subsubsection{Particle characteristics}

Hydrodynamic particle diameters (Size) were measured by dynamic light scattering on a Zetasizer 3000HS (Malvern Instruments, Worcestershire, UK) with a scattering angle of $90^{\circ}$, a wavelength of $633 \mathrm{~nm}$ and at $25^{\circ} \mathrm{C}$. Skimmed raw milks or semiskimmed UHT milks, diluted in their corresponding ultrafiltrates, were filtered on a membrane Acrodisc ${ }^{\circledR}$ with a pore size 
of $0.8 \mu \mathrm{m}$ (Pall Corporation, Ann Arbor, USA) before measurements. The refractive index for the dispersive solution was set at 1.342 and its viscosity at $0.99 \cdot 10^{-3} \mathrm{~Pa} \cdot \mathrm{s}$.

Zeta-potentials (Charge) of particles were determined with the same apparatus at $25{ }^{\circ} \mathrm{C}$ with a voltage of $125 \mathrm{~V}$. Samples were prepared as for particle size determination and the viscosity of the dispersion solution was kept at $0.99 .10^{-3} \mathrm{~Pa} \cdot \mathrm{s}$.

Hydration of casein micelles corresponded to the water content of the pellet obtained after ultracentrifugation of milk for $1 \mathrm{~h}$ at $100000 \times g$. Pellets were weighed and dried for $7 \mathrm{~h}$ at $103{ }^{\circ} \mathrm{C}$. The difference between the weight before and after drying corresponded to the value of the water content of the ultracentrifugation pellet and was expressed in $g$ of water per $g$ of dry pellet.

\subsection{Data analysis}

Measurements were made in duplicate and inserted in the database. Then the data were centred and normalised. Two multivariate statistical methods were performed with the Matlab R2006a software (The Mathworks Inc., Natic, MA, USA), i.e., principal component analysis (PCA) and common components and specific weights analysis (CCSWA).

PCA is a common technique for finding patterns in data of high dimension and for representing the maximum of information in a synthetic graph called a similarity map [23]. PCA was applied to the data to investigate differences between the samples. This technique transforms the original variables into new axes called principal components (PCs), which are orthogonal, so that the data sets presented on these axes are uncorrelated with each other. Therefore, PCA expresses, as much as possible, the total variation in the data set in only a few PCs and each successively derived PC expresses decreasing amounts of the variance. This statistical multivariate treatment was earlier used to observe similarities among different soft cheeses [17, 21], reducing the dimension to two or three PCs, while keeping most of the original information found in the data.

The objective of CCSWA, presented in detail elsewhere [24], is to determine a space of representation common to all data tables, each table having a specific weight associated with each dimension of this common space. A customdesigned CCSWA algorithm programmed in MatLab was used in this study. This version of CCSWA allowed the calculation of common dimensions, latent variables related to each data table, and loadings of each variable in the data tables. Analysis of these CCSWA outputs made it possible to explore relations between the properties of the tables and to estimate the contribution of each property in the discrimination of milks observed in this study. Each table has a specific weight (or salience) indicating its contribution in each dimension of the common space. This technique is particularly interesting to determine influential factors implicated in a process, a physicochemical reaction or in the evolution of samples as a function of time or temperature $[23,39]$.

\section{RESULTS AND DISCUSSION}

PCA was firstly carried out on the whole data set containing 420 samples and the 15 variables (matrix of $420 \times 15$ ), corresponding to all the measured parameters on the ten milks (5 from spring and 5 from autumn) before and after processing, i.e., bulk-raw milks, pasteurised milks, freshly processed UHT milks and UHT milks stored for different periods at 4, 20 and $40{ }^{\circ} \mathrm{C}$. The similarity map defined by principal components 1 and 2 showed a discrimination of samples according to the different stages of the process (results not shown). It appeared that 
the UHT sterilisation process was the principal factor modifying milk characteristics. To improve the determination of this effect and the explanatory variables, the data set with the 420 samples and the 15 variables was split into 2 data sub-sets. One sub-set contained the data recorded on bulk-raw milks, pasteurised milks and freshly processed UHT milks of the five dairy plants and for the two seasons. It was assimilated to the data set of bulk-raw and processed milks. The second sub-set contained the data recorded on UHT sterilised milks during storage, i.e. UHT milks, from the five dairy plants and for the two seasons, stored at 4,20 and $40{ }^{\circ} \mathrm{C}$ and analysed after 21 , $42,62,90,110$ and $180 \mathrm{~d}$. It was assimilated to the data set of UHT milks during storage.

\subsection{Determination of the variables explaining the discrimination of investigated bulk-raw and processed milks}

\subsubsection{Results of the Principal Component Analysis}

PCA was carried out on the sub-set including data recorded on raw, pasteurised and freshly processed UHT milks for the two seasons and for the different milking zones. Considering the PCA similarity map defined by principal components 1 and 2, raw, pasteurised and freshly processed UHT milks were well separated according to the principal component 1 (38.3\% of the total variance; Fig. 1A). This component clearly showed the effect of the sterilisation process. Raw milks were located on the positive part of the similarity map, whereas UHT milks were on the negative part. The correlation circle (Fig. 1B) showed that raw milks were characterised by high contents of NCN, total solids and fat, and high values for the ultracentrifugation-pellet water content. Oppositely, UHT milks were characterised by large particle size, and exhibited higher values for phosphate and ethanol tests than raw milks. Raw milks also presented higher $\mathrm{pH}$ and contents of soluble calcium, phosphate and proteins than UHT milks, but the weights of these variables were less significant. Contents of lactose, NPN and micellar zeta-potential were not affected by this effect, since these variables were located close to the origin of the X-axis (Fig. 1B). Minimal and maximal values for these different variables and for raw, pasteurised and freshly processed UHT milks are given in Table I. The high concentrations of total solids, fat and proteins in raw milks agreed with natural concentrations of milk before standardisation performed during industrial UHT processing. High NCN contents for raw milks were also consistent with the high contents of native whey proteins which did not precipitate at $\mathrm{pH} 4.6$ and remained in the analysed filtrate. From the correlation circle, it also appeared that raw milks had high values of ultracentrifugation-pellet water content and, oppositely, low values for heattreated milks, confirming the findings of Ruegg et al. [34]. In the same way, particles were larger in UHT milks than in their corresponding raw milks. These particles would correspond better to casein micelles than to fat globules since the UHT process included a homogenisation stage which reduced fat globule size. The increase in particle size may originate from denaturation of whey proteins induced by UHT sterilisation and their association with casein micelles, leading to an increase in casein micelle size [2]. For both raw and heat-treated milks, a negative relationship was observed between hydration and size of casein micelles, in agreement with the work of O'Connell and Fox [26]. These authors showed an increase in hydration of sedimentable protein in heated milks $\left(120{ }^{\circ} \mathrm{C}\right.$ for $10 \mathrm{~min}$ ) as the size of casein 

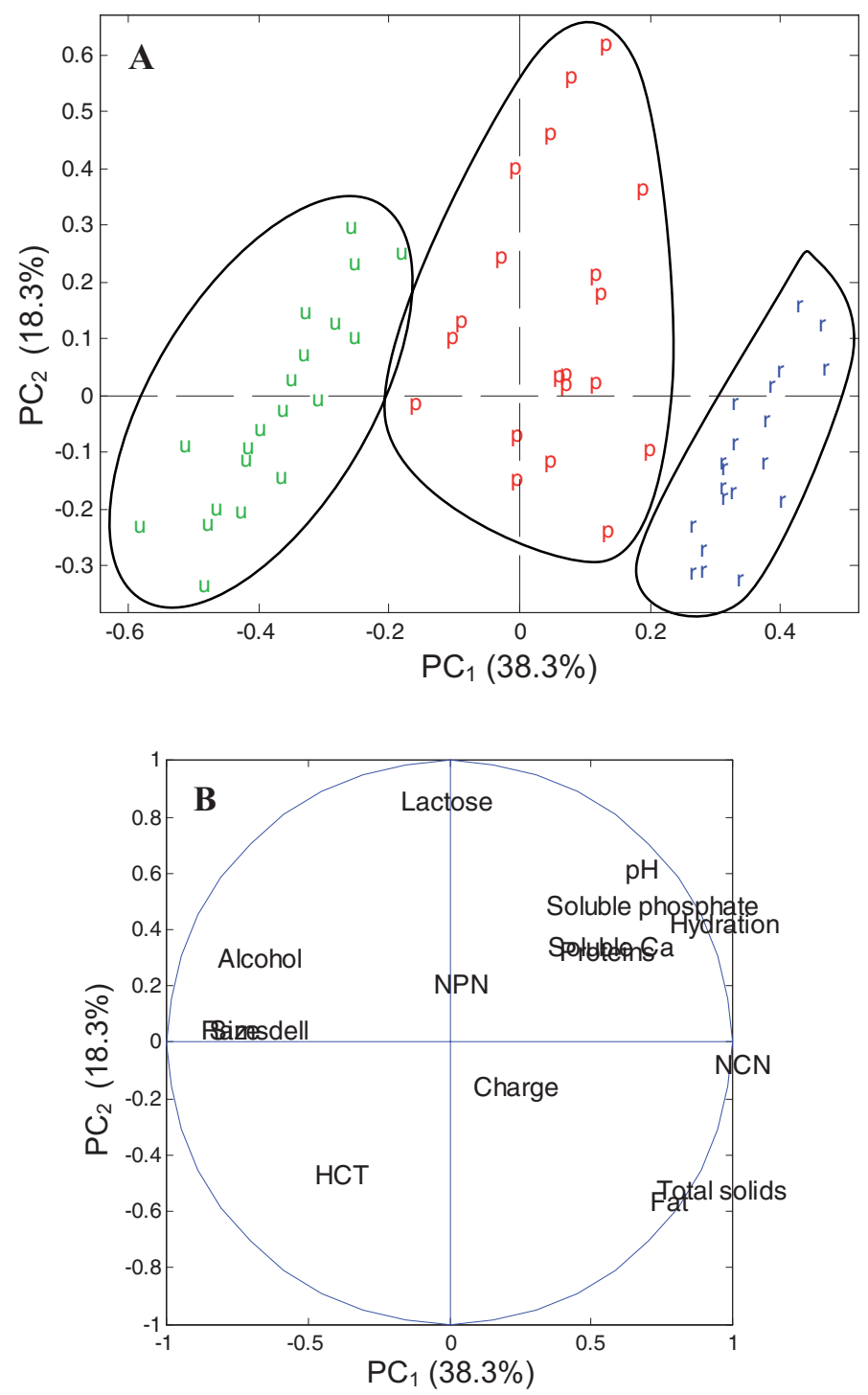

Figure 1. Principal component analysis (PCA) similarity map determined by principal components $1(38.3 \%)$ and $2(18.3 \%)$ of the PCA performed on data including raw (r), pasteurised (p) and freshly processed UHT milks (u). A: Effect of the process on the UHT milk shelf-life according to principal component 1. B: Correlation circle determined by the first two principal components of the PCA. 
Table I. Minimal (min) and maximal (max) values observed for each analysed variable and each type of milk considered in the UHT processing effect. Both minimal and maximal values corresponded to the mean value of duplicates. Values were considered from the data sub-set of bulk-raw and processed milks.

\begin{tabular}{|c|c|c|c|c|c|c|}
\hline \multirow[b]{2}{*}{ Values } & \multicolumn{2}{|c|}{$\begin{array}{l}\text { Raw } \\
\text { milks }\end{array}$} & \multicolumn{2}{|c|}{$\begin{array}{l}\text { Pasteurised } \\
\text { milks }\end{array}$} & \multicolumn{2}{|c|}{$\begin{array}{c}\text { Freshly } \\
\text { processed } \\
\text { UHT milks }\end{array}$} \\
\hline & $\min$ & $\max$ & $\min$ & $\max$ & $\min$ & $\max$ \\
\hline $\mathrm{pH}$ & 6.69 & 6.76 & 6.70 & 6.78 & 6.66 & 6.70 \\
\hline Total solids $\left(\mathrm{g} \cdot \mathrm{kg}^{-1}\right)$ & 119.8 & 129.9 & 92.3 & 114.4 & 102.0 & 105.1 \\
\hline Fat $\left(\mathrm{g} \cdot \mathrm{kg}^{-1}\right)$ & 31.4 & 42.4 & 2.0 & 26.4 & 15.2 & 16.4 \\
\hline Lactose $\left(\mathrm{g} \cdot \mathrm{kg}^{-1}\right)$ & 45.5 & 47.4 & 46.5 & 49.1 & 46.2 & 47.9 \\
\hline Proteins $\left(\mathrm{g} \cdot \mathrm{kg}^{-1}\right)$ & 33.5 & 34.8 & 33.2 & 34.9 & 33.0 & 34.9 \\
\hline $\mathrm{NCN}\left(\mathrm{g} \cdot \mathrm{kg}^{-1}\right)$ & 7.15 & 7.80 & 4.12 & 7.13 & 2.53 & 3.22 \\
\hline $\mathrm{NPN}\left(\mathrm{g} \cdot \mathrm{kg}^{-1}\right)$ & 1.40 & 1.87 & 1.41 & 1.88 & 1.22 & 2.43 \\
\hline Soluble calcium $\left(\mathrm{mmol} \cdot \mathrm{L}^{-1}\right)$ & 8.5 & 9.5 & 8.4 & 9.3 & 7.7 & 9.2 \\
\hline Soluble phosphate $\left(\mathrm{mmol} \cdot \mathrm{L}^{-1}\right)$ & 9.0 & 11.4 & 8.6 & 10.5 & 8.5 & 11.8 \\
\hline Size $(n m)$ & 173 & 212 & 181 & 251 & 232 & 294 \\
\hline Charge $(\mathrm{mV})$ & -21.9 & -13.3 & -20.5 & -18.3 & -20.9 & -18.0 \\
\hline Hydration ( $\mathrm{g}$ of water $\mathrm{g}^{-1}$ of dried pellet) & 2.19 & 2.38 & 2.17 & 2.44 & 1.88 & 2.26 \\
\hline $\mathrm{HCT}\left(\min\right.$ at $\left.140{ }^{\circ} \mathrm{C}\right)$ & 0.5 & 8.5 & 0.5 & 12.0 & 3.0 & 18.0 \\
\hline Alcohol (\% of ethanol) & 50 & 65 & 50 & 100 & 75 & 100 \\
\hline Ramsdell $\left(\mathrm{mL}\right.$ of $\left.\mathrm{KH}_{2} \mathrm{PO}_{4} 0.5 \mathrm{~mol} \cdot \mathrm{L}^{-1}\right)$ & 0.1 & 1.0 & 0.5 & 1.0 & 1.2 & 2.0 \\
\hline
\end{tabular}

micelles decreased. However, it was expected that the increase in micellar size and the decrease in ultracentrifugation-pellet water content for UHT milks induced a decrease in heat stability. As observed on the correlation circle (Fig. 1B), the results of the heat stability test did not significantly explain the discrimination of the different groups as a function of their process stage. Nevertheless, this parameter was positioned in the negative part of the circle, like phosphate and ethanol stability tests. Considering the values obtained for the different stability tests, it could be concluded that heat-treated milks were more stable than raw milks, despite micellar changes induced by heat treatments being generally considered as negative for milk stability.

\subsubsection{Results of the Common Components and Specific Weights Analysis}

The present sub-set was organised into three standardised data tables, each one corresponding to raw, pasteurised and freshly processed UHT milks. These three tables were analysed by CCSWA. This analysis allows one to create a space of representation common to these three tables in order to determine the possible existence of common structures to these tables. To simplify, it corresponds to a re-organisation of the data in multi-tables with the objective of determining some effects which affect the data. The CCSWA similarity map defined by common components 1 and 2 


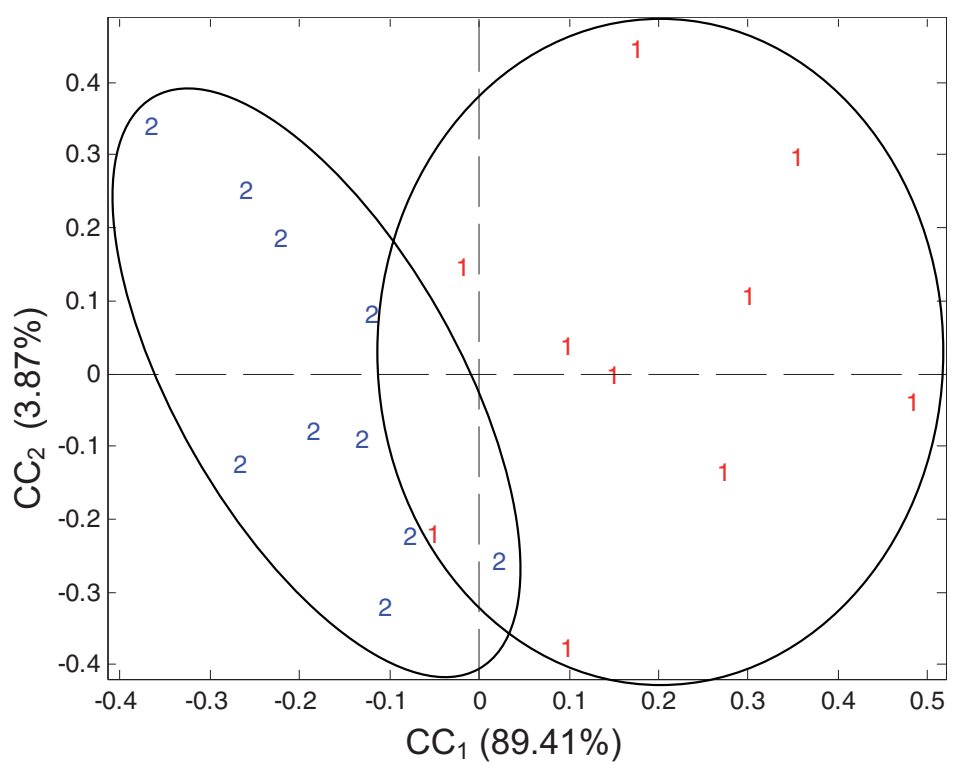

Figure 2. Common components and specific weights analysis (CCSWA) similarity map determined by common components $1(89.41 \%)$ and $2(3.87 \%)$, demonstrating the effect of season, of the CCSWA performed on the 3 data tables corresponding to raw, pasteurised and freshly processed UHT milk samples.

(Fig. 2) showed a discrimination of season 1 , on the positive part of the map, from season 2, on the negative part of the map, according to the common component 1 . The effect of season was clearly shown with this statistical analysis. The results of the weights of the 3 tables according to the first common component are presented in Table II. These weights $(0.28,0.36$ and 0.25$)$ were rather similar, indicating that raw, pasteurised and freshly processed UHT milk data contributed to the formation of the first common component. The factors responsible for this season effect can be determined according to their correlation coefficients (Tab. II). Milks collected in spring were characterised by high values of $\mathrm{pH}$, lactose, soluble phosphate, micellar hydration and a low content of fat. Raw milks collected in spring also contained larger casein mi- celles than autumn raw milks. These parameters altered by the season affected milk stability, since lower values of HCT were observed for milks collected during spring. Oppositely, contents of total solids, proteins, NCN, NPN, soluble calcium and micellar charge were not involved in the season effect. Neither ethanol stability nor phosphate stability were significantly modified. Minimal and maximal values for these different variables and for milks collected during season 1 and season 2 are given in Table III. Some of these relationships have been reported in previous papers. Indeed, Rose [32] demonstrated that high natural $\mathrm{pH}$ did not necessarily lead to a milk of high heat stability. Moreover, only high increases in soluble phosphate concentrations may contribute to increase in the buffering capacity and thus to milk heat stability. In addition, O'Connell and 


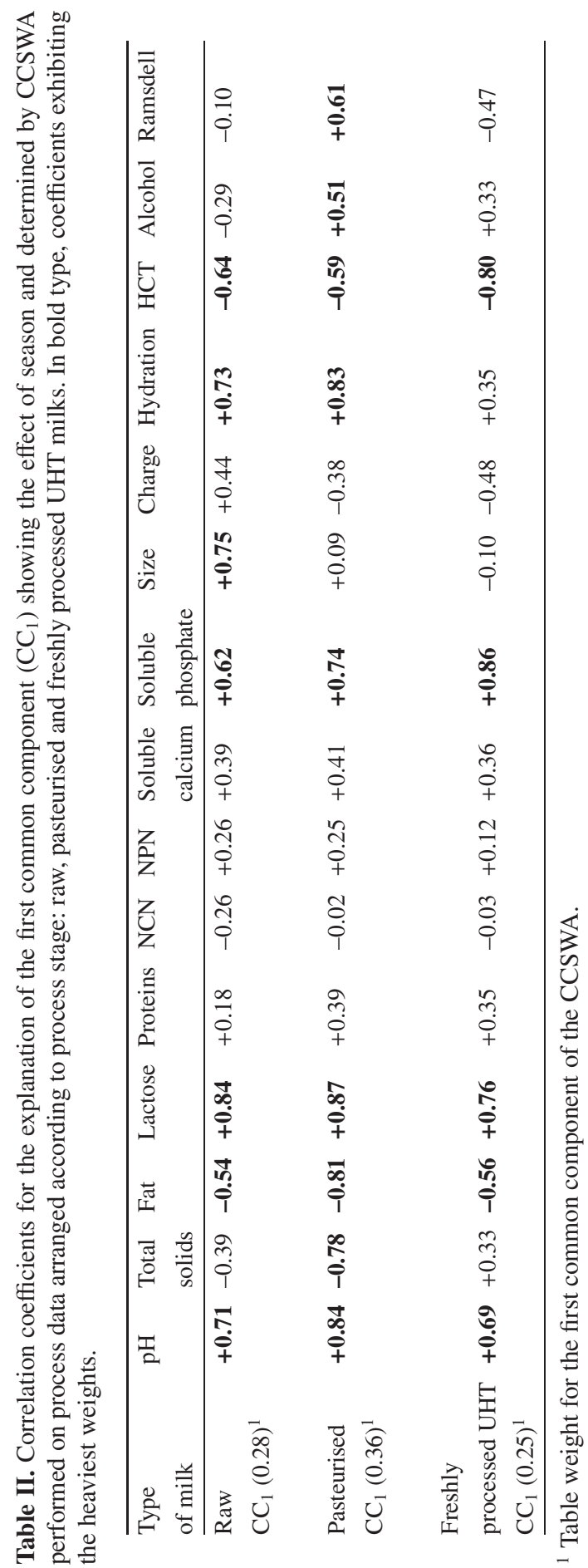


Fox [26] showed that large casein micelles negatively affected milk in the heat stability test. Changes in casein micelle size [18], fat [29] and heat stability [19] as a function of season have also been reported earlier. All these seasonal variations may be linked to lactation stage, changes in feeding or environmental conditions such as hot temperature $[1,3,20,36]$. Nevertheless, it was not possible to evaluate the weights of these parameters from this study because the investigated samples were bulk milks.

The obtained results allowed the demonstration of the effects of UHT processing and season and to determine the involved physico-chemical parameters.

\subsection{Determination of the effects observed during UHT milk storage}

\subsubsection{Results of the Principal Component Analysis}

The considered data set in this section corresponded to the parameters measured on UHT milks, collected in the two seasons and in the five dairy plants, after different storage periods $(21,42,62,90,110$ and $180 \mathrm{~d})$ at different temperatures $(4,20$ and $40{ }^{\circ} \mathrm{C}$ ). A PCA was carried out on this data set and the PCA similarity map defined by the first two principal components is presented in Figure 3A. The first principal component $\left(\mathrm{PC}_{1}\right)$, which accounted for $23.6 \%$ of the total variance, discriminated UHT milks according to their storage temperature. The effect of storage temperature was clearly observed here. A net discrimination was observed between the group of milks stored at $40{ }^{\circ} \mathrm{C}$, on the negative part of the $\mathrm{PC}_{1}$, and the groups of milks stored at 4 and $20{ }^{\circ} \mathrm{C}$, on the positive part of the $\mathrm{PC}_{1}$. Milks stored at $40{ }^{\circ} \mathrm{C}$ were characterised by high contents of NCN and NPN and low values of $\mathrm{pH}$ (Fig. 3B). Minimal and maximal values for these different variables and for
UHT milks stored at 4,20 and $40{ }^{\circ} \mathrm{C}$ are given in Table IV. These changes, suggesting proteolysis and acidification, were in agreement with many physico-chemical and enzymatic reactions promoted by high storage temperatures [14]. Milks stored at $40{ }^{\circ} \mathrm{C}$ also presented low heat stability values but high stability values for the phosphate test (Fig. 3B, Tab. IV). This opposition in the results of stability tests may be related to the principle of each test. In the heat stability test, heat treatment at $140{ }^{\circ} \mathrm{C}$ induces acidification, whey protein denaturation, Maillard reaction and casein hydrolysis [13]. In the phosphate test, the addition of large amounts of phosphate before heat treatment at $100{ }^{\circ} \mathrm{C}$ leads to a decrease in $\mathrm{pH}$, mineral imbalance, solubilisation of caseins from casein micelles, aggregation and changes in particle hydration $[15,33,38]$. It could be suggested that lactosylation of caseins in UHT milks stored at $40{ }^{\circ} \mathrm{C}$ may obstruct the mechanism of milk destabilisation in the phosphate test by changes in the particle hydration or by inhibition of particle aggregation, as proposed by Samel et al. [35]. This may explain why large volumes of phosphate were necessary to destabilise UHT milks stored at $40{ }^{\circ} \mathrm{C}$ and why the milk stability in the phosphate test was higher than the milk stability evaluated by the heat stability test.

Except for these changes in heat and phosphate stability test values and the modifications of $\mathrm{pH}$ and $\mathrm{NCN}$ and NPN contents, no other parameter seemed significantly involved in the storagetemperature effect.

\subsubsection{Results of the Common Components and Specific Weights Analysis}

In order to extract more information about the variables which could be responsible for alteration of UHT milks, the present data set was re-organised into three 
Table III. Minimal (min) and maximal (max) values observed for each analysed variable and each type of milk considered in the season effect. Both minimal and maximal values corresponded to the mean value of duplicates. Values were considered from the data sub-set of bulk-raw and processed milks.

\begin{tabular}{|c|c|c|c|c|}
\hline \multirow[b]{2}{*}{ Values } & \multicolumn{2}{|c|}{ Milks from season 1} & \multicolumn{2}{|c|}{ Milks from season 2} \\
\hline & $\min$ & $\max$ & $\min$ & $\max$ \\
\hline$\overline{\mathrm{pH}}$ & 6.67 & 6.78 & 6.66 & 6.77 \\
\hline Total solids $\left(\mathrm{g} \cdot \mathrm{kg}^{-1}\right)$ & 92.3 & 129.6 & 102.6 & 129.9 \\
\hline Fat $\left(\mathrm{g} \cdot \mathrm{kg}^{-1}\right)$ & 2.0 & 41.4 & 15.3 & 42.4 \\
\hline Lactose $\left(\mathrm{g} \cdot \mathrm{kg}^{-1}\right)$ & 46.2 & 49.1 & 45.5 & 47.1 \\
\hline Proteins $\left(\mathrm{g} \cdot \mathrm{kg}^{-1}\right)$ & 33.4 & 34.9 & 33.0 & 34.8 \\
\hline $\mathrm{NCN}\left(\mathrm{g} \cdot \mathrm{kg}^{-1}\right)$ & 2.53 & 7.80 & 2.65 & 7.73 \\
\hline $\mathrm{NPN}\left(\mathrm{g} \cdot \mathrm{kg}^{-1}\right)$ & 1.55 & 2.09 & 1.22 & 2.43 \\
\hline Soluble calcium $\left(\mathrm{mmol} \cdot \mathrm{L}^{-1}\right)$ & 8.4 & 9.5 & 7.7 & 9.3 \\
\hline Soluble phosphate $\left(\mathrm{mmol} \cdot \mathrm{L}^{-1}\right)$ & 9.0 & 11.8 & 8.5 & 10.3 \\
\hline Size $(n m)$ & 186 & 272 & 173 & 294 \\
\hline Charge $(\mathrm{mV})$ & -21.5 & -13.3 & -21.9 & -17.2 \\
\hline Hydration ( $\mathrm{g}$ of water $\cdot \mathrm{g}^{-1}$ of dried pellet) & 1.92 & 2.44 & 1.88 & 2.27 \\
\hline $\mathrm{HCT}\left(\min\right.$ at $\left.140{ }^{\circ} \mathrm{C}\right)$ & 0.5 & 7.0 & 4.5 & 18.0 \\
\hline Alcohol (\% of ethanol) & 50 & 100 & 50 & 100 \\
\hline Ramsdell $\left(\mathrm{mL}\right.$ of $\left.\mathrm{KH}_{2} \mathrm{PO}_{4} 0.5 \mathrm{~mol} \cdot \mathrm{L}^{-1}\right)$ & 0.1 & 1.8 & 0.2 & 2.0 \\
\hline
\end{tabular}

Table IV. Minimal (min) and maximal $(\max )$ values observed for each analysed variable and each type of milk considered in the storage temperature effect. Both minimal and maximal values corresponded to the mean value of duplicates. Values were considered from the data sub-set of UHT milks during storage.

\begin{tabular}{|c|c|c|c|c|c|c|}
\hline \multirow[b]{2}{*}{ Values } & \multicolumn{2}{|c|}{$\begin{array}{c}\text { Milks stored } \\
\text { at } 4{ }^{\circ} \mathrm{C}\end{array}$} & \multicolumn{2}{|c|}{$\begin{array}{l}\text { Milks stored } \\
\text { at } 20^{\circ} \mathrm{C}\end{array}$} & \multicolumn{2}{|c|}{$\begin{array}{l}\text { Milks stored } \\
\text { at } 40{ }^{\circ} \mathrm{C}\end{array}$} \\
\hline & $\min$ & $\max$ & $\min$ & $\max$ & $\min$ & $\max$ \\
\hline$\overline{\mathrm{pH}}$ & 6.60 & 6.75 & 6.57 & 6.72 & 6.19 & 6.64 \\
\hline Total solids $\left(\mathrm{g} \cdot \mathrm{kg}^{-1}\right)$ & 101.1 & 105.8 & 103.0 & 106.2 & 102.0 & 106.5 \\
\hline Fat $\left(\mathrm{g} \cdot \mathrm{kg}^{-1}\right)$ & 15.1 & 16.6 & 14.0 & 16.8 & 13.1 & 17.0 \\
\hline Lactose $\left(\mathrm{g} \cdot \mathrm{kg}^{-1}\right)$ & 46.1 & 48.5 & 46.5 & 48.5 & 45.8 & 48.1 \\
\hline Proteins $\left(\mathrm{g} \cdot \mathrm{kg}^{-1}\right)$ & 32.1 & 35.4 & 33.0 & 35.5 & 33.1 & 35.8 \\
\hline $\mathrm{NCN}\left(\mathrm{g} \cdot \mathrm{kg}^{-1}\right)$ & 2.64 & 4.14 & 2.65 & 4.23 & 2.84 & 6.14 \\
\hline $\mathrm{NPN}\left(\mathrm{g} \cdot \mathrm{kg}^{-1}\right)$ & 1.46 & 2.16 & 1.55 & 2.16 & 1.60 & 3.15 \\
\hline Soluble calcium $\left(\mathrm{mmol} \cdot \mathrm{L}^{-1}\right)$ & 6.4 & 11.1 & 6.2 & 11.1 & 6.1 & 11.2 \\
\hline Soluble phosphate $\left(\mathrm{mmol} \cdot \mathrm{L}^{-1}\right)$ & 6.6 & 16.7 & 7.3 & 12.9 & 7.5 & 15.0 \\
\hline Size $(\mathrm{nm})$ & 226 & 300 & 227 & 295 & 213 & 287 \\
\hline Charge $(\mathrm{mV})$ & -20.8 & -17.3 & -22.5 & -16.9 & -21.0 & -16.5 \\
\hline Hydration ( $\mathrm{g}$ of water $\mathrm{g}^{-1}$ of dried pellet) & 1.75 & 2.40 & 1.71 & 2.30 & 1.77 & 2.34 \\
\hline $\mathrm{HCT}\left(\min\right.$ at $\left.140^{\circ} \mathrm{C}\right)$ & 5.0 & 24.5 & 2.9 & 20.0 & 2.0 & 18.5 \\
\hline Alcohol (\% of ethanol) & 85 & 100 & 80 & 100 & 75 & 100 \\
\hline Ramsdell $\left(\mathrm{mL}\right.$ of $\left.\mathrm{KH}_{2} \mathrm{PO}_{4} 0.5 \mathrm{~mol} \cdot \mathrm{L}^{-1}\right)$ & 1.4 & 2.6 & 1.5 & 2.9 & 1.2 & 3.9 \\
\hline
\end{tabular}



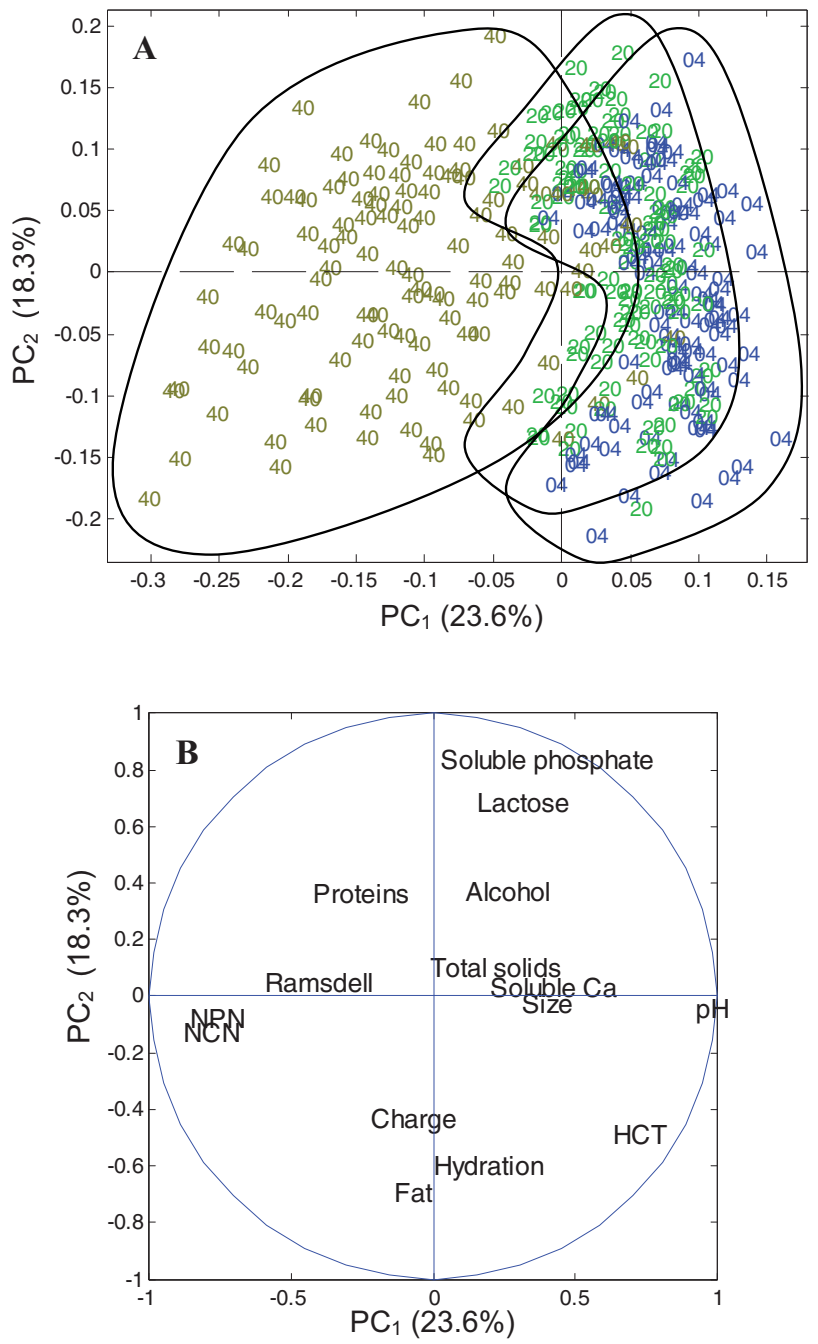

Figure 3. Principal component analysis (PCA) similarity map determined by principal components $1(23.6 \%)$ and $2(18.3 \%)$ of the PCA performed on storage data for UHT milk samples stored at 4,20 and $40{ }^{\circ} \mathrm{C}$ for different storage periods. A: Effect of storage temperature according to principal component 1. B: Correlation circle determined by the first two principal components of the PCA.

normalised data tables, each one corresponding to UHT milks stored at a given temperature, i.e., 4, 20 and $40{ }^{\circ} \mathrm{C}$. CCSWA was performed on these three data tables. The results (not shown) showed that the season effect was still observed dur- ing storage. This indicated that the initial differences in raw milks still remained in UHT milks, independently of storage conditions. In order to go further and more deeply into the evaluation of the data, this data set was divided into two sub-sets 

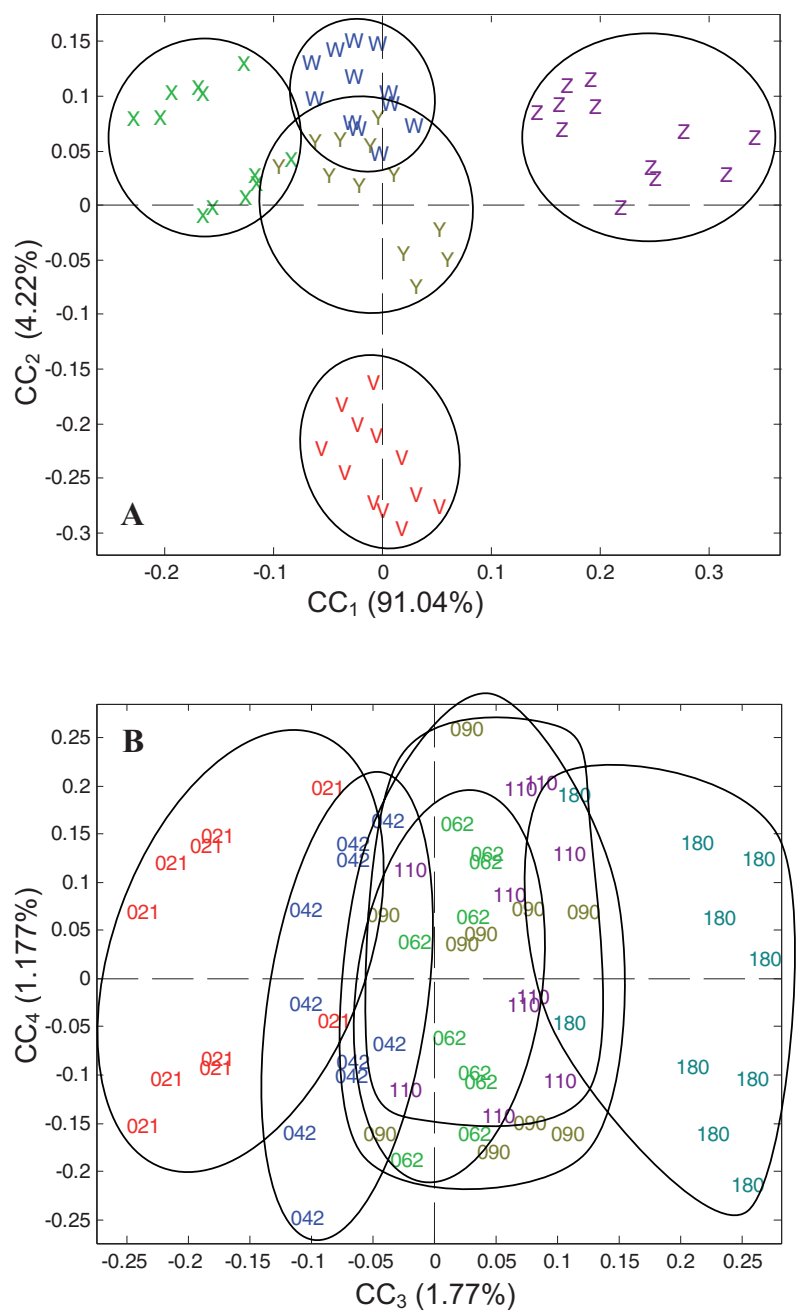

Figure 4. Common components and specific weights analysis (CCSWA) similarity maps determined by common components $1(91.04 \%)$ and $2(4.22 \%)$, demonstrating the effect of dairy plants (A), and by common components $3(1.77 \%)$ and $4(1.177 \%)$, demonstrating the effect of storage time (B), of the CCSWA performed on the 3 data tables corresponding to UHT milk samples stored at 4,20 and $40{ }^{\circ} \mathrm{C}$ (for $21,42,62,90,110$ and $180 \mathrm{~d}$, season 2).

corresponding to season 1 and season 2 . As similar results were obtained for seasons 1 and 2, we chose to present the results obtained from CCSWA performed on the data of season 2 .

The CCSWA, performed on the data sub-set corresponding to UHT milks of season 2, from the five dairy plants and stored at 4,20 and $40{ }^{\circ} \mathrm{C}$ for different times, showed a discrimination of the samples as a function of the dairy plants according to the first two common components (Fig. 4A). This effect of dairy plants, which could be associated 


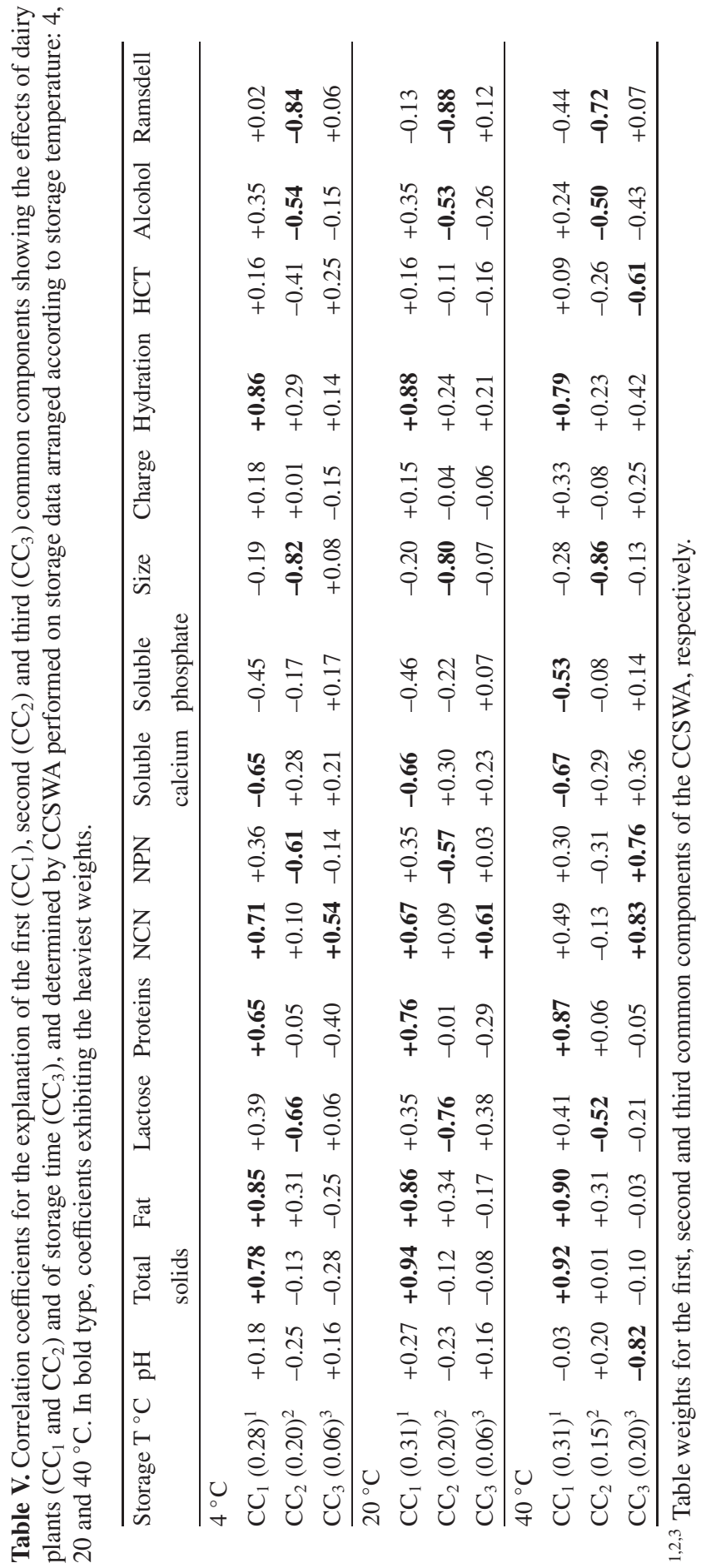




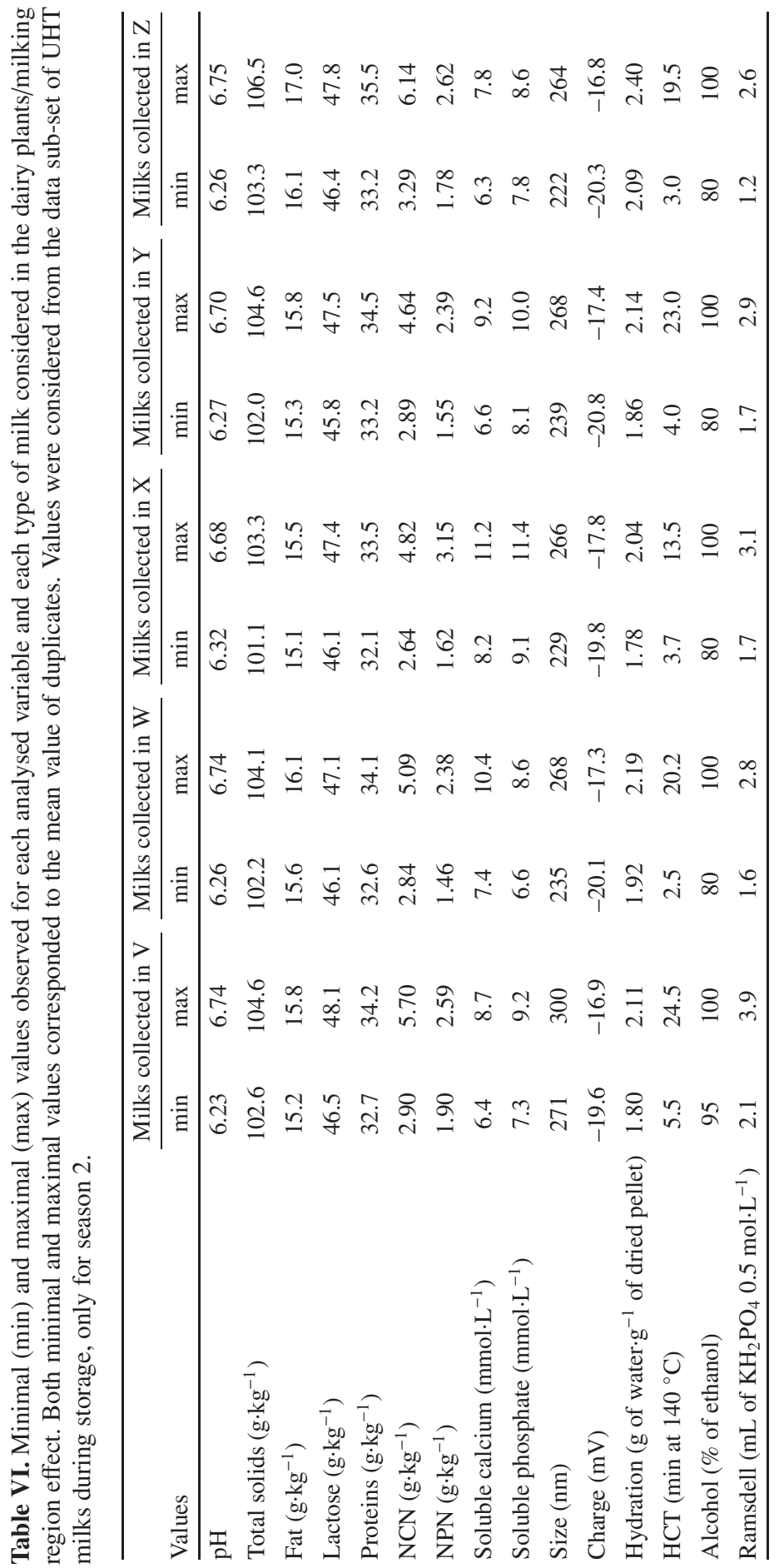


with an effect of the milking region (cow breed, feed, herd management, climate) or of the processing conditions of each dairy plant (time/temperature pair for pasteurisation and sterilisation, pressure of homogenisation, industrial practice), was clearly observed here. Common component $1\left(\mathrm{CC}_{1}\right)$, accounting for $91.04 \%$ of the total variance, discriminated principally the dairy plant $X$, on the negative part of the map, from the dairy plant $\mathrm{Z}$ (Fig. 4A). The weights of the tables were similar $(0.28,0.31$ and 0.31$)$, as shown by the values of saliences reported in Table V, i.e., each table participated equally in the building of the common component 1 . Samples of the dairy plant $\mathrm{Z}$ had higher contents of total solids, fat, proteins, NCN, higher values for micellar hydration and lower contents of soluble calcium than the ones from dairy plant $\mathrm{X}$. No change in milk stability was observed according to $\mathrm{CC}_{1}$ (Tab. V). Common component 2, which accounted for $4.22 \%$ of the total variance, discriminated samples of the dairy plant $\mathrm{V}$, on the negative side of $\mathrm{CC}_{2}$, from those of the dairy plant $\mathrm{W}$, on the positive side of $\mathrm{CC}_{2}$ (Fig. 4A). As the weights of the tables were similar $(0.20,0.20$ and 0.15$)$, it could be concluded that all the tables participated in the building of common component 2 (Tab. V). Samples from the dairy plant $\mathrm{W}$ had lower contents of lactose and NPN, and smaller casein micelles than those from the dairy plant V. These differences altered milk stability values in the tests, and samples of the dairy plant $\mathrm{W}$ had lower stability values in ethanol and phosphate tests than samples of dairy plant $\mathrm{V}$ (Tab. V). Minimal and maximal values for these different variables and for UHT milks from the dairy plants $\mathrm{V}, \mathrm{W}, \mathrm{X}, \mathrm{Y}$ and $\mathrm{Z}$ are given in Table VI. All the physicochemical characteristics studied were involved in this dairy plant effect with the exception of the parameters $\mathrm{pH}$, content of soluble phosphate and micellar charge. Changes in physico-chemical characteris- tics resulted in changes in the ethanol and phosphate tests results but not in the heat stability test result.

As shown in Figure 4B, common component 3 discriminated UHT milks as a function of their storage time even if it accounted for only $1.77 \%$ of the total variance. The samples stored for $21 \mathrm{~d}$ were on the negative part of $\mathrm{CC}_{3}$ and those stored for $180 \mathrm{~d}$ were on the positive part. Considering the values of saliences in the different data tables (Tab. V), it was noticed that the data table " $40{ }^{\circ} \mathrm{C}$ " had a heavier weight than the two others $(0.20$ versus 0.06$)$. Consequently, the table containing data on UHT milks stored at $40{ }^{\circ} \mathrm{C}$ mainly contributed to the building of common component 3 and explained the discrimination. UHT milks stored for long periods, and notably at $40{ }^{\circ} \mathrm{C}$, were characterised by lower values of $\mathrm{pH}$, higher contents of $\mathrm{NCN}$ and NPN and were easily destabilised when submitted to the heat stability test. Minimal and maximal values for these different variables and for UHT milks stored for 21, 42, 62, 90, 110 and $180 \mathrm{~d}$ are given in Table VII. These findings agreed with the results obtained for the temperature effect during storage reported in Section 3.2.1. The time/temperature pair has to be taken into account when the effect of storage on the quality of UHT milk is investigated.

\section{CONCLUSION}

To our knowledge, this study was the first one attempting to investigate the different effects which alter commercial UHT milk shelf-life, starting with the sampling of raw milks and ending with UHT processed milks stored for several months at 4, 20 and $40{ }^{\circ} \mathrm{C}$. To investigate the characteristics of the samples as a function of the milking zone and the alterations in UHT milk samples during storage, the initial global and large data set was divided into smaller ones and analysed thanks to two multidimensional statistical tools, i.e., 


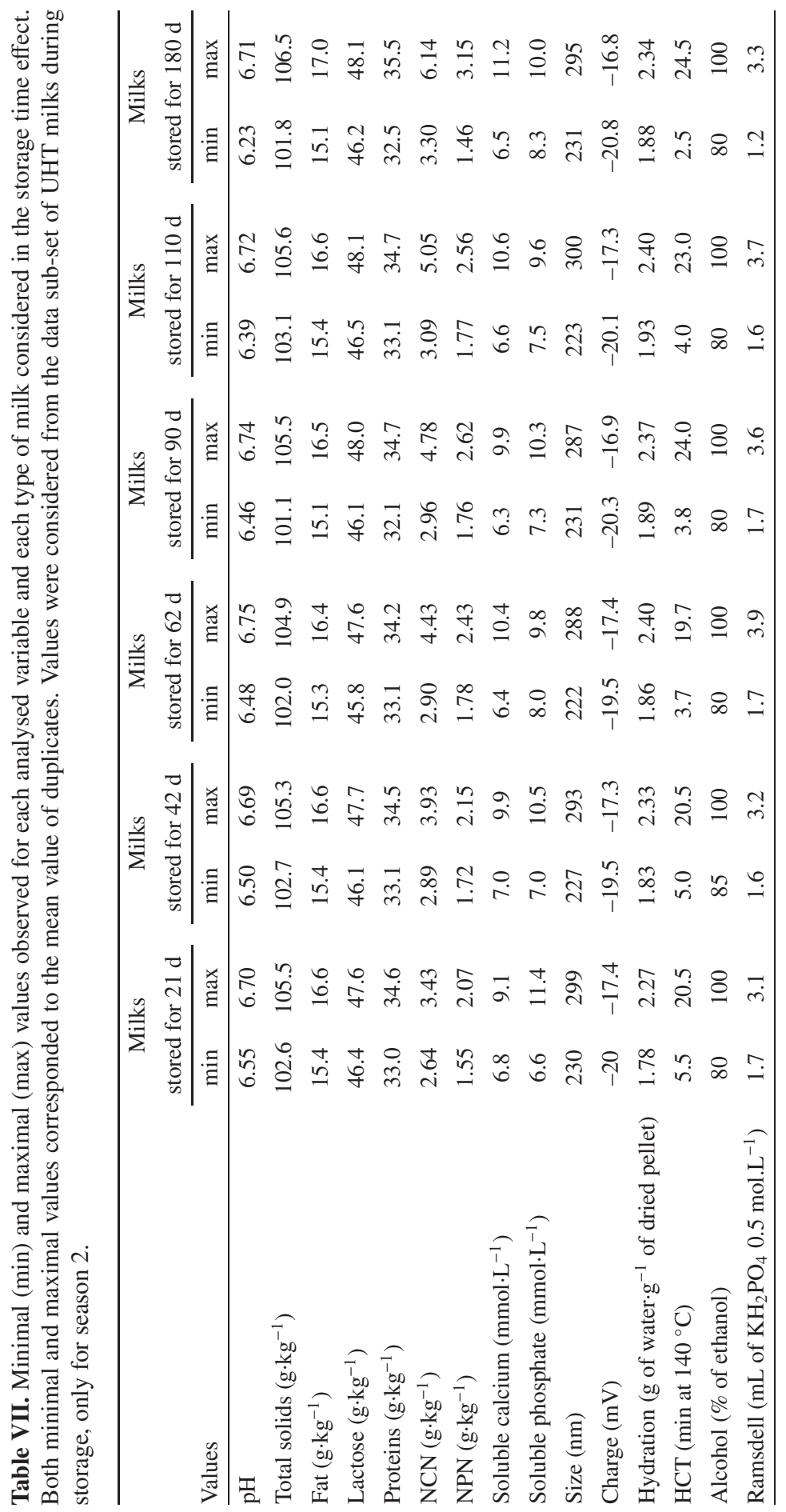




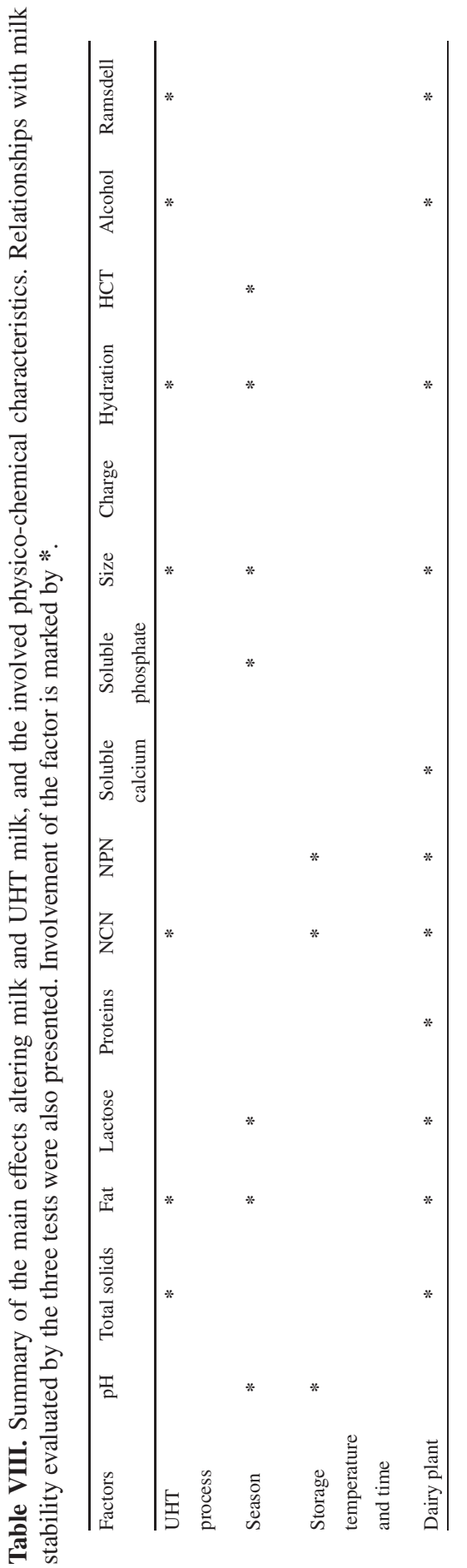




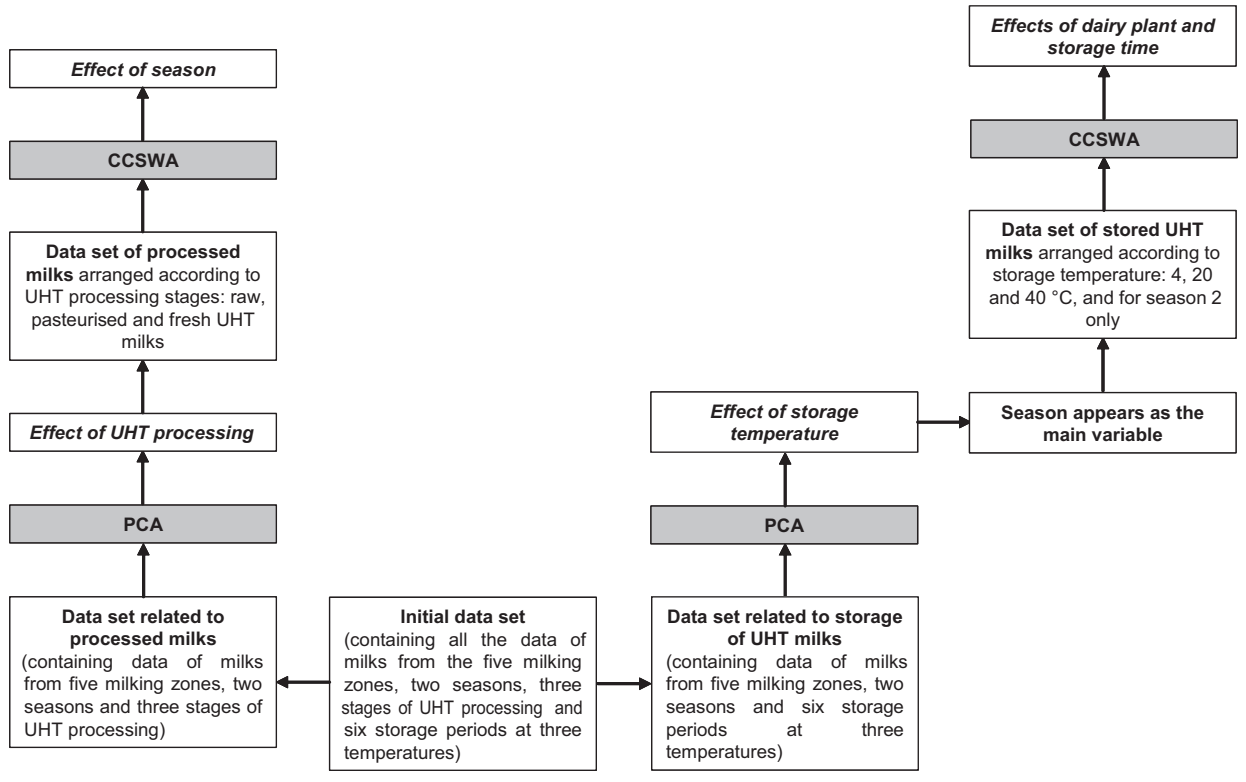

Figure 5. Recapitulative scheme of the different data sets analysed, the chemometric tools used, and the different alterations demonstrated in milk samples.

PCA and CCSWA. Figure 5 summarises the different data sets analysed, the chemometric tools used and the observed effects. These effects corresponded to UHT processing, season, storage conditions and milking zone/dairy plant. Table VIII summarises the physico-chemical characteristics involved in these different effects. This study, based on the use of chemometric tools allowing the investigation of the relations between several data tables, has brought out a global view of the parameters altering milk and UHT milk shelf-life. It also showed that the three milk stability tests did not evaluate milk stability in the same way, and that milk stability evaluated by these different tests was not always linked to the same changes in casein micelle properties. This study contributed to a better knowledge of effects which affect milk and UHT milk characteristics. It is important in order to improve quality of raw material and consequently those of final products. However, additional studies are needed. For a better knowledge of the parameters implicated in milk stability, it will be necessary to analyse other milk characteristics, and especially other casein micelle properties. In addition, some effects such as lactation stage, feed or environmental conditions should be taken into account for a better explanation of dairy plant/milking zone or season effect.

Acknowledgements: The authors would like to thank Arilait Recherches (Association of French Dairy Manufacturers and Farmers) and French dairy manufacturers for financial support, supplying milk samples and general discussion. Dr. D. Bertrand (ENITIAA/INRA Nantes, France) is acknowledged for providing PCA and CCSWA processing programs. 


\section{REFERENCES}

[1] Alais C., Science du lait, in: Principe des techniques laitières, 4th edition, SEPAIC, Paris, France, 1984.

[2] Anema A.T., Li Y., Association of denatured whey proteins with casein micelles in heated reconstituted skim milk and its effect on casein micelle size, J. Dairy Res. 70 (2003) 73 83.

[3] Auldist M.J., Walsh B.J., Thomson N.A., Seasonal and lactational influences on bovine milk composition in New-Zealand, J. Dairy Res. 65 (1998) 401-411.

[4] Boixo J.C., Kaabi M., Alvarez M., Abroug B., De la Fuente L.F., Anel E., Anel L., Causes of variation in milk production of cows in the Castilla y Leon Region, in: Djemali M., Guellouz M. (Eds.), Prospects for a Sustainable Dairy Sector in the Mediterranean - EAAP 99, Wageningen Academic Publishers, Wageningen, The Netherlands, 2003, pp. 57-61.

[5] Bony J., Contamin V., Gousseff M., Metais J., Tillard E., Juanes X., Decruyenaere V., Coulon J.B., Factors of variation of the milk composition on the Reunion Island, INRA Prod. Anim. 18 (2005) 255-263.

[6] Brulé G., Maubois J.-L., Fauquant J., Étude de la teneur en éléments minéraux des produits obtenus lors de l'ultrafiltration du lait sur membrane, Lait 54 (1974) 600-615.

[7] Datta N., Deeth H.C., Age-gelation of UHT milk - a review, Trans. IChemE Part C 79 (2001) 197-210.

[8] Datta N., Elliott A.J., Perkins M.L., Deeth H.C., Ultra-high-temperature (UHT) treatment of milk: comparison of direct and indirect modes of heating, Aust. J. Dairy Technol. 57 (2002) 211-227.

[9] Davies D.T., White J.C.D., The stability of milk protein to heat. I. Subjective measurement of heat stability of milk, J. Dairy Res. 33 (1966) 67-81.

[10] Davis S.R., Farr V.C., Knowles S.O., Lee J., Kolver E., Auldist M., Sources of variation in milk calcium content, Aust. J. Dairy Technol. 56 (2001) 156.

[11] Devold T.G., Brovold M.J., Langsrud T., Vegarud G.E., Size of native and heated casein micelles, content of protein and minerals in milk from Norwegian Red Cattle - Effect of milk protein polymorphism and different feeding regimes, Int. Dairy J. 10 (2000) 313-323.
[12] Formaggioni P., Franceschi P., Summer A., Malacarne M., Fieni S., Mariani P., Effects of the season and the herd on milk proteose peptone content and relationships with rennet-coagulation properties, Sci. Tec. Latt. Casearia 53 (2002) 53-65.

[13] Fox P.F., Heat-induced changes in milk preceding coagulation, J. Dairy Sci. 64 (1981) 2127-2137.

[14] Gaucher I., Mollé D., Gagnaire V., Gaucheron F., Effects of storage temperature on physico-chemical characteristics of semi-skimmed UHT milk, Food Hydrocoll. 22 (2008) 130-143.

[15] Gaucher I., Piot M., Beaucher E., Gaucheron F., Physico-chemical characterization of phosphate-added skim milk, Int. Dairy J. 17 (2007) 1375-1383.

[16] Gaucheron F., Le Graët Y., Piot M., Boyaval E., Determination of anions of milk by ion chromatography, Lait 76 (1996) 433-443.

[17] Herbert S., Mouhous Riou N., Devaux M.F., Riaublanc A., Bouchet B., Gallant D.J., Dufour E., Monitoring the identity and the structure of soft cheeses by fluorescence spectroscopy, Lait 80 (2000) 621-634.

[18] Holt C., Muir D.D., Natural variations in the average size of bovine casein micelles. II. Milk samples from creamery bulk silos in south-west Scotland, J. Dairy Res. 45 (1978) 347-353.

[19] Holt C., Muir D.D., Sweetsur W.M., Seasonal changes in the heat stability of milk from creamery silos in south-west Scotland, J. Dairy Res. 45 (1978) 183-190.

[20] Horne D.S., Parker T.G., Donnelly W.J., Davies D.T., Factors affecting the ethanol stability of bovine skim milk. VII. Lactational and compositional effects, J. Dairy Res. 53 (1986) 407-417.

[21] Karoui R., Dufour E., Dynamic testing rheology and fluorescence spectroscopy investigations of surface to centre differences in ripened soft cheeses, Int. Dairy J. 13 (2003) 973-985.

[22] Karoui R., Martin B., Dufour E., Potentiality of front-face fluorescence spectroscopy to determine the geographic origin of milks from the Haute-Loire department (France), Lait 85 (2005) 223-236.

[23] Karoui R., Mazerolles G., Dufour E., Spectroscopic techniques coupled with chemometric tools for structure and texture determinations in dairy products, Int. Dairy J. 13 (2003) 607-620. 
[24] Mazerolles G., Hanafi M., Dufour E., Bertrand D., Qannari E.M., Common components and specific weights analysis: a chemometric method for dealing with complexity of food products, Chemometr. Intell. Lab. 81 (2006) 41-49.

[25] McMahon D.J., Age-gelation of UHT milk: changes that occur during storage, their effect on shelf life and the mechanism by which age-gelation occurs, in: Heat Treatments \& Alternative Methods, Int. Dairy Fed., Brussels, Belgium, 1996, pp. 315-326.

[26] O'Connell J.E., Fox P.F., The two-stage coagulation of milk proteins in the minimum of the heat coagulation time-pH profile of milk: effect of casein micelle size, J. Dairy Sci. 83 (2000) 378-386.

[27] O’Connell J.E., Fox P.F., Heat-induced coagulation of milk, in: Fox P.F., McSweeney P.L.H. (Eds.), Advanced Dairy Chemistry, 3rd edition, Kluwer Academic/Plenum Publishers, New York, USA, 2003, pp. 879945.

[28] Othmane M.H., Carriedo J.A., De la Fuente L.F., San Primitivio F., Factors affecting testday milk composition in dairy ewes, and relationships amongst various milk components, J. Dairy Res. 69 (2002) 53-62.

[29] Palmquist D.L., Beaulieu A.D., Barbano D.M., ADSA Foundation Symposium: milk fat synthesis and modification. Feed and animal factors influencing milk fat composition, J. Dairy Sci. 76 (1993) 1753-1771.

[30] Pierre A., Brulé G., Mineral and protein equilibria between the colloidal and soluble phases of milk at low temperature, J. Dairy Res. 48 (1981) 417-428.

[31] Ramsdell G.A., Johnson W.M.T., Jr., Evans F.R., A test for the detection of milk unstable to heat, J. Dairy Sci. 14 (1931) 93-106.
[32] Rose D., Variations in the heat stability and composition of milk from individual cows during lactation, J. Dairy Sci. 44 (1961) 430441.

[33] Rose D., Tessier H., Effects of various salts on the coagulation of casein, J. Dairy Sci. 42 (1979) 989-997.

[34] Ruegg M., Blanc B., Luscher M., Hydration of casein micelles: kinetics and isotherms of water sorption of micellar casein isolated from fresh and heat-treated milk, J. Dairy Res. 46 (1979) 325-328.

[35] Samel R., Weaver W.V., Gammack D.B., Changes on storage in milk processed by ultra-high-temperature sterilization, J. Dairy Res. 38 (1971) 323-332.

[36] Sanchez W.K., McGuire M.A., Beede D.K., Macromineral nutrition by heat stress interactions in dairy cattle: review and original research, J. Dairy Sci. 77 (1994) 2051-2079.

[37] Sommer H.H., Binney T.H.A., A study of the factors that influence the coagulation of milk in the alcohol test, J. Dairy Sci. 6 (1923) 176-197.

[38] Udabage P., McKinnon I.R., Augustin M.-A., Mineral and casein equilibria in milk: effects of added salts and calcium-chelating agents, J. Dairy Res. 67 (2000) 361-370.

[39] Vigneau E., Qannari E.M., Jaillais B., Mazerolles G., Bertrand D., Méthodes prédictives, in: Bertrand D., Dufour E. (Eds.), La Spectroscopie Infrarouge et ses Applications Analytiques, 2nd edition, Tec et Doc, Paris, France, 2006, pp. 347-401.

[40] Walker G.P., Dunshea F.R., Doyle P.T., Effects of nutrition and management on the prediction and composition of milk fat and protein: a review, Aust. J. Agric. Res. 55 (2004) 1009-1028. 